\title{
The Elderly's Media Appropriation as Variable for Target Groups
}

\author{
REBEKKA HAUBOLD \& SONJA GANGUIN, Leipzig University, Germany
}

\begin{abstract}
Media and media appropriation can be the basis for diversity and also for commonalities, describing target groups more exactly than the chronological age approach does. This paper demonstrates why it is necessary to expand the view of target groups beyond mere classification in the category of age, especially when the focus is placed on the elderly. It establishes that there are other possibilities than age to find also appropriate classification categories for the elderly by means of media appropriation combined with Bourdieu's forms of capital. This paper suggests that, regardless of whether media use, education or media literacy, if the media research is intended to reach fruitful ends, its instruments need to be developed with media specifically in mind. In this case, they need to be subject-orientated in relation to the media appropriation of the elderly.
\end{abstract}

\section{KEYWORDS}

media appropriation, target groups, the elderly, capitals, diversity, media education

\section{Introduction}

Naming 'the elderly' implies referring to a diverse target group. Target groups are common within the educational research and analysis as well as in the practical experience, because it is fruitful to establish differences and similarities between group members regarding the aims of the project. Even so, target groups in media educational research are mainly derived from the age of the group members. For example, the concept of media competence ${ }^{1}$ is commonly geared towards such target groups as children, youth, adults or the elderly. This arrangement might make sense in the case of babies or children due to their similar physical and mental development within similar lifecourses. In contrast to childhood and adolescence, the life of adults and the elderly is more distinguished by increasing variable life situations and circumstances with advancing age (Schenk 2011). This diversity is based on several aspects such as personal options, talents and interests as well as political liberalism with rising individualisation and a high standard of living, which generate many and variable opportunities for acting (Baltes und Nesselroade 1979; Jäckel 2010). In terms of media and their development

\footnotetext{
${ }^{1}$ The choice of the term 'media competence' over the concept of 'media literacy' is intended, because of the different point of view and scientific genesis of both terms. While media literacy is used in AngloAmerican debate (Livingstone 2004), and follows a pragmatic standing, 'media competence' will be used as an equivalent for the German term 'Medienkompetenz' with its theoretical background and idealistic participatory meaning (Ganguin et al. in print).
} 
during the last decade, these vast developments have broadened various possibilities, similarities in experience and differences. The article presents a possibility how acting with media - described with the concept of media appropriation - can be used to linked to the independence of aged people.

\section{Chronological Age as a Confuted Influence}

The group of elderly people is mostly defined through chronological age, although this definition includes a group of highly diverse people (Haubold 2015). For the elderly, the new media currently present with the changes of digitalisation are clearly essential (Jörissen and Marotzki 2009, 7; Aufenanger 2008, 88), and important considerations when examining media appropriation, but so too are the past influencing variables (medial and non-medial) (Baltes and Schaie 1973). Equally, one past influence that must be considered for research into media appropriation is the subjects' primary socialisation, which has no less important influence with increasing age (Hartung 2007, 67-79). Because of this fact, the frequently used categorisation 'age' - within the meaning of 'date of birth' - in research into media education could be a good choice describing elderly's similarities, because the same birth years could 'produce' similarly socialised people. Referred to Bernice L. Neugarten, this category is named historical-time (1979, 364). The historical-time is comprehensible because structural life contexts and long-term situations - such as political and economic systems - are often constant and lead to equal fields of acting. In the case of media, those historical-time-managed influences are not consistently determined by certain years. For example, the difference of media appropriation by today's elderly, who were socialised during the same years within a divided Germany after the Second World War, is significant. This is the case, for example, due to their general socialisation through the different political systems (German Democratic Republic GDR, Federal Republic of Germany FRG) and on the other hand through differences in media content, implementation (colour TV or VCR) and related media-repertoire (Schorb 1995, 95).

In addition to historical-time, Bernice L. Neugarten defines life-time and social-time ${ }^{2}$, which leads to fewer differences between the elderlies past media appropriation (1979, 364). With such generation- or life-time groups (Mannheim 1970; Zinnecker 2003; Böhnisch 2012), a greater similarity is to be expected because the contexts in which media appropriation is embedded, show more similarities and this is due to equal content-similarities. In the case of media as mediator, media appropriation could be very similar. Despite, there is still the problem that the historical-time category creates: those who are/were not involved in the mainstream (e.g. generation of '68), cannot be described collectively (Zinnecker 2003, 47). Furthermore, technical differences - when media is the object of appropriation - still are not explained sufficiently. In the current discussion there is a frequently-used category dealing with connecting life-time with the

\footnotetext{
2 Social-time means the time that structures the course of the life of a person, such as, for instance, childhood or puberty (Becker 2008, 206) while life-time determines in which social-time a person experiences a historical-time period (Neugarten 1979, 365).
} 
technical aspects of media. It is described as dividing individuals into 'digital natives' and 'digital immigrants' (Prensky 2001). As a media-based category, it is a nice attempt at finding similarities such as technical familiarity. The problem with this categorisation is that this concept cumulates in a group that is very different in its preconditions of appropriation (Kübler 2012a, 2012b) because other aspects (especially content-aspects) are disregarded. Eventually, the concept is still reduced to fixed years; neither life-time nor historical-time nor other contexts are variables considered in this approach. Therefore, it is more one of the many approaches that defame the elderly rather than being a useful instrument for research. Moreover, it should be the aim of research to abolish discrimination; as Frank Schirrmacher puts it, 'We need to declare war on the defamation of age. ${ }^{3}(2004,33)$.

It is necessary to find an additional approach, which solves the problem of agediscrimination and vast diversity among the elderly. For example, there are concepts such as life-long-learning and active-agers, which implicitly positive discriminate elderly people by age or normative downgrades such as the term 'digital immigrants'. Both can lead to real psychological and motivational problems in aging (Schneider-Flume $2008,43)$. On the other hand, there are approaches, which try to abolish discrimination. One attempt is describing age no longer as a deficit (Engel 2013; Gehrke 2004; Kubicek and Welling 2000) e.g. as a claim to participation (Hartung 2009; Künemund 2001; Patzwaldt und Staudinger 2012; Stadelhofer und Marquard 2012). Another step, could be, to describe scientific phenomena no longer on the basis of age. For example, several subject-centred approaches focus on different non-media-categories such as biological, physical or mental changes (Simon et al. 1999, 29), life-time situations of flux such as the exit from working life, the death of a spouse, contracting disease(s) (Doh 2011; Jahoda et al. 1980; Kruse 2011; Schenk 2011; Kruse 2002) or on biographical differences, interests and routines (Hartung 2009). Other rare approaches focus on media-orientated similarities or differences such as media equipment and prior knowledge (Böhnisch 2012; Kübler 2012b; Pietraß und Grengs 2012), which could occur at any stage of the life course. Accordingly, media appropriation could be added to the media-orientated non-age-descriptions of the elderly.

\section{From Media Appropriation to Contexts}

Media appropriation is a suitable concept to describe similarities and differences between groups of people - in a mediatised world (Krotz, 2008, 23; Jenkins 2008), where acting can always be acting with and through media - because it describes acting and interaction within its contexts. Appropriation is the process by which an individual develops a learned skill/ability thus appropriating it to its own skill/ability (Leontjev 1973, 240). The individual is able to apply and improve, change or develop this 'new, own' skill/ability (Leontjev 1973, 240; Hurrelmann 1995, 158; Geulen 2005, 313). If as-

${ }^{3}$ Own translation of: '[Wir müssen] der Diffamierung des Alters den Krieg erklären.' 
sumed that the subject is acting freely and with self-determination, it cannot be seen as profitable to deal with the term of media 'use'. Rather, it makes sense to deal with the concept of 'appropriation.' Therefore, media is, on the one hand, the object of appropriation, because media are human-made and their content also construct society (Geulen 2005, 216). Due to this, Alexej N. Leontjev characterises appropriation as the 'most important ontogenetic evolutionary principle' $(1973,235)$ because it reproduces history and defines a human being - and thus an individuals' - skills, abilities and attitudes. At the same time, to use these abilities, a mediator is necessary (Leontjev 1973, 236). For this, media also can, on the other hand, be the mediator (Leontjev, 1973, 236) of the content which is/has been appropriated.

Within the scope of media education in Germany, Bernd Schorb and Helga Theunert (2000) define the term of media appropriation with a view on media as mediator. They divide the process into four steps through which the individual passes. In the beginning, the subject perceives the medium as object of appropriation itself or as medium in and of itself. In the second step, the individual understands with the help of past appropriation and within her/his contexts and already available skills and abilities. Nearly simultaneously - described in a third step - the content is evaluated with personal categories. For the last - fourth step - the understood content will be applied and processed, which means that the individual transfers the new skills and abilities and integrates them into her/his thinking and actions (Schorb 2009, 183). In Bernd Schorb's (2009) definition, it is necessary to practically use media, thereby the newly appropriated skills and abilities can be applied physically as well as mentally. Furthermore, Schorb mentions that the contexts, especially everyday life, are important for media appropriation $(2009,183)$. This might sound banal but it is not less important to describe and research an individual solely in her/his own contexts.

This leads to the conclusion that media appropriation is embedded in the singular context and personal life-world (referring to Edmund Husserl's concept (Zelić 2008) of the individual and the single appropriation situation (Leontjev 1973, 246; Hurrelmann 1995, 162; Schorb 2009)). The personal life-world is the 'constituted real environment of experiences and possibilities for action. It is the lifeworld, in which education and socialisation take place and for this encompasses and determines every human communication ${ }^{4}$ (Baacke 2007, 52). This suggests that, appropriation forms society and is also embedded in society. Every appropriation depends on the society, situation and the object, which defines the possibilities for action; age-independently. Thus, if media are viewed as mediator, similarities in interaction with them and in appropriation of the content are also similarities in media appropriation. For this, media appropriation could be added to other categories - such as age - as variable for target groups. It can be a connecting element between target group members.

\footnotetext{
${ }^{4}$ Own translation of: Die persönliche Lebenswelt ist die ,konstituierte reale Umwelt von Erfahrungen und Handlungsmöglichkeiten. Sie ist der Lebensraum, in dem sich Erziehung und Sozialisation abspielen und der damit alle Kommunikationen eines Menschen bestimmt und umfaßt .
} 


\section{Describing Diverse and Similar Contexts with Bourdieu's Capitals}

An individual has not only their own repertoire of skills and abilities, but with this their own singular preconditions for media appropriation (Geulen 2005, 215). Furthermore, an individual is part of their society and has, with they place in this society, individual possibilities for action. To describe methodically this possibilities of action, this section offers the combination of two theories about people's contexts: Klaus Hurrelmann states that action - and thus also interacting with media - is embedded in the subject's 'inner' and 'outer reality' $(1995,162)$. To fill this concept a point of view for a new approach here could be Pierre Bourdieu's capitals $(1983,190)$. In his system-critical description, Bourdieu categorises fields of action, which describe the possibilities of action an individual has. Even if his theory had other intentions, the concept was and is useful for social science research (Schulze 1997, 20) because it concentrates and covers a broad range of human action and interaction. Thus, the approach can be adopted beneficially to media appropriation.

On the assumption that the subject has an inner and an outer reality, which are mutually influenced (Hurrelmann 1995), it is necessary to apply Bourdieu's categories to both of them. In combination with Pierre Bourdieu's capitals $(1983,190)$, describing inner reality is connected with inherited capital, social and cultural as well as economic. An aspect which is not described with these categories - but important in the debate about media appropriation of individuals - is how to describe the fields of action, which are immanent parts of the individual, for example those, that are needed during the subject perceives media as content or mediator. Therefore, a new form of capital is added to the concept: the inherited 'physical and mental capital' (including genetic characteristics), which is derived from Klaus Hurrelmann's model of innate subject immanent influencing variables $(1995,276)$ and can be supplemented by Bourdieu's concept of habitus, which both subsume societal and personal attitudes and values $(1999,104)$.

For media appropriation, the selection process is fundamental because every action has an aim. Aims are dependent on the situation and individual interests (Lauber and Krapp 2013, 97), which e.g. furthermore depend on attitudes, values, motivations, needs, heuristics, moods, emotions or previous knowledge (Früh 1991; Gigerenzer and Gaissmaier 2011; Goldstein and Gigerenzer 1996; Katz et al. 1973; Mahrt 2014; Matthes 2014; Katz et al. 1973; Schenk 2007). These subject immanent influencing physical and mental capitals are decisive because media appropriation is started by the individual and is bound by the individual's skills and abilities (Geulen 2005, 215). For perception and processing during media appropriation, skills such as hearing or seeing are needed to listen or watch. For processing, mental capital such as cognitive skills and abilities are important. Concerning the elderly, a noteworthy cognitive change is the decrease in long-term and short-term memory (Matthes 2014, 18), as well as sensory-motor influencing variables. Inherited cultural capital, which is subject immanent, could include (especially through the process of primary socialisation) language level, societal or familial values, emotions, assessment systems or communication practices (Renckstorf 
1977; Hurrelmann 1995, 158). Also strongly connected with primary socialisation, is the inherited social capital. The social network in which an individual is born (e.g. in the form of family, or superordinate citizenship, religious and society affiliation as well as the tightness of the relationship and the number of interaction partners), forms the basis for further social relationships and also is more resilient than others (Bourdieu 1983, 190). Interaction, and in particular, interaction with media when media are objects or mediators of communication, is defined by the possibilities the social capital offers. Inherited economic capital includes not just available money but also any object that is 'convertible' directly into money (Bourdieu 1983, 185), which refers for example to media equipment. These are the fields of inner reality in which the individual has her/his action-possibilities.

The outer reality can also be composed of these forms of capital. Media as objects can be seen as cultural capital, or rather as objectified cultural capital (Bourdieu 1983, 189). Media-repertoire describes the media appropriation aspect of both objectified cultural capital and economic capital, when media are used as objects, with their (arising) costs, value or availability (e.g. when they cannot be purchased because they are too expensive; when they cannot receive channels or the internet because of a missing network). Moreover, institutionalised cultural capital describes the knowledge possibilities an individual has because of her/his formal and non-formal education (ibid.), which could include media-literacy, technical knowledge, usability, and thus nevertheless content-related knowledge.

Regarding the appropriation of new media, non-formal processes should predominate in quantity whereas formal education should be of a higher grade of quality. Bourdieu $(1983,190)$ also divides the field of social capital into two areas: institutionalised (e.g. through marriage, or party affiliation) and non-institutionalised social capital (e.g. neighbours, friends or peers). For media appropriation this is not just crucial because of the possibility or necessity to communicate through and with mediator media, but also for media as objects, when the capital of the relational partners can be used and therewith the economic and cultural capital of the individual can be grown exponentially (e.g. the media-repertoire or literacy). This context of the relational partners is often overlooked in media research, although it could be a significant influencing variable, especially with regards to the media appropriation habits of the elderly.

In order to analyse the media appropriation of an individual, the focus needs to be expanded to encompass the framework conditions, in which subject and media are embedded (Geulen 2005, 215). Behind every culture there is a balance of power, which has the power of definition (Berger und Luckmann 2004; Marchart 2011), which structures the society and with this the individual's life-world and possibilities of action. These contexts are crucial, on the one hand, for the individual's culture with its structures and laws, and, on the other hand, for the cultural praxis of the appropriated media. This is particularly true when media are used to legitimate (economic or political) power (Hepp 2010, 78). Those definitions influence the fields of action through laws, values, and 
structures (Hepp 2010, 74). A deep interpretation in the manner of cultural studies should not be a part of the presented concept but ideas from this field can be used as a fertile impulse when regarding an individual's contexts. In an enlightened manner, the media education researchers (e.g. Baacke et al. 1990; Schorb 1995; Hüther und Podehl 2010) attach importance to this in their research and try to establish media competence as a critical ability to identify and investigate such imbalances of power. Bernd Schorb states how decisive structures of power and cultural capital are $(1995,186)$. An individual can only act independently and maturely if it is able to see through the structures of power and comprehend its role within them. Additionally, the subject's action depends on her/his everyday life. Media appropriation is a part of everyday life. Therefore every named possible influence is embedded in it and a comprehensive view needs to both focus on it (Paus-Hasebrink 2013, 36) as well as on non-everyday-life incidents such as life caesuras.

Nearly all of these possible influences are age-independent. But goals and possibilities act in accordance with the abilities and previous experience of the media appropriation of each subject, since they accumulate with growing age and the corresponding diversity rises. It could be postulated that the more each individual is like another person, the more the media appropriation of these people matches, irrespective of age.

\section{Age as a Less Determining Context}

Regarding all these contexts, it is clear that, whilst age is one factor, it is not the only factor that influences media appropriation. The following will show how past analyses can be reinterpreted by applying the conceived capital-based concept.

One common definition of the elderly within the field of educational research is people who have retired from active working life. Nowadays the field of pensioners is characterised by broad diversity. If the exceptions of early retirement are not taken into account, then in Germany retirees can be between 63 and 112 years old ${ }^{5}$. Even if chronological age were an influencing factor, an age category spanning nearly 50 years cannot describe a highly differentiated group, as it treats all within the group as a homogenous mass of 'old people'. Unfortunately, however, important surveys often treat the individuals in this category as one group (e.g. ARD/ZDF-Onlinestudie 60+ (Frees and Koch 2015)). Some researchers, however, do acknowledge this difference and divide old age pensioners into age categories, for instance, young-elderly (60-65) and old-elderly (80 or $85+$ ) people (DZA 2016) or younger-elderly (55/60-75), middle-elderly (75$80 / 85+)$, elderly (75-90) and very elderly (90+); sometimes the group of $100+$ appears in the descriptions (Menning and Hoffmann 2009).

The free ranging scale of the age categories clarify how arbitrary they are, especially regarding other age ranges (such as early childhood, childhood or adolescence) because

${ }^{5}$ In Germany, the eldest current retiree was born on 28.01.1904 (dpa 25.05.15 10:42). 
the age groups for the elderly do not orientate themselves on five-year periods. One reason for this is that these categories orientate themselves towards the development or circumstances, which are defined through the course of working-life with preschool, school, secondary school forming the basis for the divisions. People in retirement, however, no longer participate in this meaningful structure. Therefore, it only makes sense to focus on the caesura retirement - age-independently. In the case of media appropriation, this caesura could be interesting because the various capitals change with it: from one day to the next, economic, social and cultural capital as well as everyday life can rapidly change. Less income, for example, can influence media repertoire (economic capital), a removal from working life can imply losing regular contact with co-workers (social capital) and their capital (cultural capital). Whereby more leisure time gained through retirement can lead to longer or more intensive media appropriation with a wider media repertoire. It seems, therefore, that age or caesura can be replaced because the changing capitals are more significant, which explains the ' $w h y$ ' of media appropriation and does not just describe what is changing.

How strong these changes are derived probably more from capitals than from age or the life-caesura retirement. It is not necessary to know why an element of social capital such as co-workers ceases (because of retirement, age or because of a conflict), rather it is important to know that this change is happening and what it means for media appropriation.

\section{Gender as Less Determining Context}

An also age-independent aspect, which is often and arbitrarily set as a variable influence, is gender. Another interpretation, with the introduced concept, would regard gender not merely dichotomised into two or three categories (e.g. male, female, transgender). Instead it could be considered as inherited physical and mental, and cultural capital. Like other values, gender is cultural and socially negotiated (Wegener 2008, 44; Kogan 1979, 252). The possibilities are as variable as society and culture define their expectations (Hurrelmann 1995, 257). Therefore, it could be useful, to see and interpret gender as potentials of action which are possible for the individuals in the moment in which they act; and in special cases, in which they act with media. Therefore, not just age, also gender (as example for other socio-demographics) needs to be reinterpreted concerning media appropriation.

Some research findings connect age with gender, although the capitals behind both of them are equal and also discussable. For example, Michael Doh points out, that equalities between the media repertoire and gender increase with increasing age $(2011,237)$. This should show the strong connection to societal values because some kinds of media were more, some less, received by either men or women. Doh interprets newspapers as a typically elderly's male medium $(2011,237)$, without thinking about further contexts, which could be also relevant: newspaper-reception, as a male dominated activity, could 
simply be due to the fact that elderly women - e.g. because of their role as housewives and mothers - have less time or (regarding the content) less interest because of their job or social network in traditional newspaper categories (such as economy, sport or politics). For working women, this difference between men and women is unexpected. It is more a difference between people with interests in newspaper's content or practiced profession. On the one hand, gender is not the influencing variable, but rather the possibility of and interest for media appropriation. On the other hand, such interest reasons change as well as gender roles change. For the elderly, these times could also change. Maybe they have grown up in a world dominated by men but now they are emancipated - or not - similar to the way younger people are - or not - emancipated. For this reason, age for itself is less relevant than socio-cultural and political contexts and ideologies or personal circumstances. Gender is also less relevant as well it is therefore a problematic category. The contexts of inherited cultural capital and specifics in society's fields of action can say more about similarity in media appropriation than those aspects do.

\section{Physical and Mental Capital as Considerable Determining Contexts}

When applying the capital concept introduced above to the problem of target groups, it becomes clear that the elderly's media appropriation can be very diverse (Haubold 2015) likewise, the capitals could originate similarities. With increasing age, physical capital tends to decrease (Horn 1979; Weise 2007; Ziegler 2008). This is crucial for media appropriation in the state of perceiving; for example, when pressing buttons, tunes and auditory signals are recommended beyond visual information as declines in visual, auditory and haptic sensations tend to occur (Menning and Hoffmann 2009; Horn 1979) and influence media appropriation. Auditory deficits mostly can be compensated with volume control, whereas haptic or visual abilities influence the appropriation of media in regards to content as well as media as mediator. For visual content such as print-products, TV or tablets and smartphones, it means that there can be differences in understanding on the one hand. On the other hand, auditory media (which do not need visual abilities) also require other sensory skills to be initiated, for example through haptic or visual processes (e.g. by pushing the right buttons at the right moment). This combination of processes is widely diverse in computer game appropriation for example. These changes are often misunderstood as lacking motor skills, which deteriorate not only with greatly increasing age (Horn 1979, 306; Doh 2011, 74), but rather depend more on repetitive use (Saß et al. 2009, 31).

For example, while playing a game, it could be possible that a younger subject has with regard to their visual abilities - an advantage, but this person's motor skills are not different to those of the older subject. As a logical consequence of the theoretical data it could be stated, that the elderly person is the better video gamer because their skills have been honed through regular practice. Regular practice has enabled the elderly person to develop the best skills for video games. This demonstrates yet again that many influencing variables are not age-dependent because two people of the same age could 
have the same skill discrepancies as well. To put it differently, for example, if one person is near-sighted and has forgot their glasses, but is more familiar with the game, the appropriation would be similar because it is less connected with age than it is connected with the subjects' varying capitals - and in this case connected with media repertoire and visual abilities.

The target group of the elderly also is not different from other groups in its media appropriation when regarding mental capital. If physical capital would adhere to the concept of age, two groups of people would exist: Cognitive abilities begin to decrease starting at the age of thirty (Becker 2008, 207), which means (following the same arbitrary line of logic) that if groups were created based on age, then one of these groups should contain people up to thirty while the other contains people over thirty years of age. This is no fruitful step. For this, it could be a good addition to regard physical capital age-independently. There is less age-dependent loss in long- and short-term memory (Horn 1979, 298), both of which are crucial for processing during media appropriation. They depend on individual selection (such as interests or object stimuli) and repetition (Matthes 2014, 16), which means they are age-independent and similarities can be seen in the subjects' capitals. If an elderly person does appropriate a medium (no matter if for the content or as a mediator), the appropriated medium can remain in the person's memory much as it does in the memory of a younger person (Horn 1979, 298). At the same time, it is possible that, when appropriating new media, the elderly can compensate for deficits through their life experiences. Visual abilities, for instance, can be reconstructed with the help of such associational skills.

\section{Practical Example 'Medienclub Leipziger Löwen'6}

In summary, the more people are like each other, the more their media appropriation matches; and this occurs age-independently. The cross-generational media project 'Medienclub Leipziger Löwen', demonstrates this aspect. The group members presently are in the process of creating an app together. Some of the participants are not even users of a smartphone or tablet. It is important to note that (in opposition to the statistics (Frees et al. 2015)), it is not just the older people involved in the media project who lack any kind of tablet or smartphone. In addition, some of the younger members are still without these media devices. The motivation of our old and young members alike for not using smartphones sounds straightforward: they do not need them because their friends and family can contact them by (standard mobile) phone and they are satisfied with this means of communication.

\footnotetext{
6 The 'Medienclub Leipziger Löwen' (Media-Club Leipzig's Lions) is an intergenerational volunteering group of the GAM e.V. (Gesellschaft Alter(n) Medien e.V.), which realises in peer-learing-processes and on the basis of learning-by-doing several media projects according to the topic age since 2010. The youngest member is 25 , the eldest 86 years old. (Further information about the group and projects at: www.leipziger-loewen.org ).
} 
Furthermore, they know about the advantage of the mobile internet, but for both groups it is sufficient to surf the internet and answer emails on their PC at home or work (Haubold 2016). For them, it does not matter how old they are, or which gender they have. Their social capital as well as their media repertoires connect them in their media appropriation. As an illustration, based on their media-literacy regarding smartphones, it is possible to conclude what is relevant for the practical work and where the methods and visualisations need to be adapted. For example, the participants do not work with their own media devices, but rather in groups with others or with paper and pencil. Explanations need to be more detailed in general, but they can build on what is similar to internet use on a PC, a field with which they are familiar. In fact, the only two members of our club who have their own tablets are over fifty years of age (Haubold 2016). Both of them have social-capital and media-repertoire reasons for owning a tablet: they want to Skype with their families and do not want to use a PC for this purpose.

This practical example is, obviously, only a first sampling. More similarities linking various groups still need to be discovered. It does, however, represent a small-scale study example for practical experience according to the theoretical considerations about the forms of capital as categories as explored above.

\section{Conclusion: The Elderly's Media Appropriation}

After thorough exploration of the examples above, it becomes clear that the current target groups model cannot be unproblematically mapped onto the elderly due to their diversity. The elderly's actions with media is varied, and not just because of their age. The 'age' of a person as a definition for target groups must be strongly criticised and reflected upon. A more informative approach could be accomplished by using Pierre Bourdieu's forms of capital - supplemented by physical and mental capital - which stake out the fields of action that an individual has, interacting with media and for the means of media appropriation. Explicit similarities need to be found. However, it is important for researchers as well as for practitioners to understand these similarities as a means to knowing about the subjects' media-literacy. For this, the approach is not just crucial for practical work - because didactic methods or content can be adapted - also it can be profitable for media-science in general whenever research is done on, into or using target groups. Media appropriation as subject-orientated and media-orientated point of view can be more reflective about the contexts of people, than age. Overall, it makes sense to focus on similar capitals instead of or additional to aspects defined by the people's age because the elderly are not a silver target group, they seem to be gaudy in their media appropriation. 


\section{References}

Aufenanger, S. (2008) 'Mediensozialisation', in U. Sander, F. von Gross and K.-U. Hugger (eds), Handbuch Medienpädagogik, Wiesbaden: VS Verl. für Sozialwiss, pp. 87-92.

Baacke, D. (2007) Medienpädagogik (Grundlagen der Medienkommunikation, 1), Tübingen: Niemeyer.

Baacke, D.; Sander, U.; Vollbrecht, R. (1990) Lebenswelten sind Medienwelten (Medienwelten Jugendlicher, 1), Opladen: Leske + Budrich.

Baltes, P. B.; Nesselroade, J. R. (1979) 'Die entwicklungspsychologische Analyse von individuellen Unterschieden in mehreren Meßgrößen', in P. B. Baltes and Lutz H. Eckensberger (eds), Entwicklungspsychologie der Lebensspanne (Klett-Cotta/Psychologie Forschung), Stuttgart: Klett-Cotta, pp. 145-178.

Baltes, P. B.; Schaie, K. W. (eds), (1973): Life-span developmental psychology. Personality and socialization, New York, London: Acad. Press.

Becker, H. A. (2008) 'Karl Mannheims 'Problem der Generationen' - 80 Jahre danach'[online], in Zeitschrift für Familienforschung, 20 (2), pp. 203-221. Available at http://www.ssoar.info/ssoar/bitstream/handle/document/26971/ssoar-zff-2008-2becker-karl_mannheims_problem_der_generationen.pdf?sequence $=1$. Accessed 9 January 2015.

Berger, P. L.; Luckmann, T. (2004) Die gesellschaftliche Konstruktion der Wirklichkeit. Eine Theorie der Wissenssoziologie (Vol. 20) (Fischer, 6623), Frankfurt am Main: Fischer-Taschenbuch-Verl.

(English version: Berger, P.L.; Luckmann, T. (1966) The Social Construction of Reality. A Treatise in the Sociology of Knowledge. London: Penguin Books. Available at http://perflensburg.se/Berger\%20social-construction-of-reality.pdf. Accessed 12 May 2016.

Böhnisch, L. (2012) 'Lebensalter, Generation und Medien', in A. Hartung (eds), Generationen und Medienpädagogik. Annäherungen aus Theorie, Forschung und Praxis (Gesellschaft - Altern - Medien, 4), München: kopaed, pp. 65-86.

Bourdieu, Pierre (1983) 'Ökonomisches Kapital, kulturelles Kapital, soziales Kapital', in R. Kreckel (eds), Soziale Ungleichheiten (Soziale Welt : Sonderband, 2), Göttingen: Schwartz, pp. 183-198.

Bourdieu, P. (1999) 'Die feinen Unterschiede. Kritik der gesellschaftlichen Urteilskraft' (Vol. 11) (Suhrkamp-Taschenbuch Wissenschaft, 658), Frankfurt am Main: Suhrkamp.

Doh, M. (2011): Heterogenität der Mediennutzung im Alter. Theoretische Konzepte und empirische Befunde (Gesellschaft - Altern - Medien, Bd. 2), München: kopaed.

dpa (25.05.15 10:42): 'Die älteste Frau Deutschlands kommt jetzt aus Bayern' [online], in Merkur, 25.05.15 10:42. Available at http://www.merkur.de/bayern/aelteste-fraudeutschland-kommt-jetzt-bayern-margarete-dannheimer-111-jahre-lby-5042119.html. Accessed 15 June 2016. 
DZA (2016) 'Altern im Wandel: Zwei Jahrzehnte Deutscher Alterssurvey (DEAS)' [online], in K. Mahne, J. K. Wolff, J. Simonson \& C. Tesch-Römer (eds), Berlin: Deutsches Zentrum für Altersfragen (DZA). Available at https://www.dza.de/fileadmin/dza/pdf/DEAS2014_Langfassung.pdf. Accessed 12 May 2016.

Engel, B. (2013) 'Mediennutzung im Alter: Analysen zur Medienausstattung und Mediennutzung auf Basis der Studie Massenkommunikation 1970-2010', in Medien \& Altern - Zeitschrift für Forschung und Praxis, 3, pp. 9-31.

Erikson, E. H. (1973) Identität und Lebenszyklus. Drei Aufsätze (SuhrkampTaschenbuch Wissenschaft, 16), Frankfurt am Main: Suhrkamp.

Frees, B.; Koch, W. (2015) 'ARD/ZDF-Onlinestudie 2015. Internetnutzung: Frequenz und Vielfalt nehmen in allen Altersgruppen zu', Media Perspektiven, 9, pp. 366-377.

Früh, W. (1991) 'Medienwirkungen: Das dynamisch-transaktionale Modell. Theorie und empirische Forschung' [online]. Available at http://dx.doi.org/10.1007/978-3-66310777-4. Accessed 08 November 2014.

Ganguin, S., Gemkow, J. \& Haubold, R. (in print) 'Information Overload as a Challenge and Changing Point for Educational Media Literacies', in R. Marques, Rui \& J. Batista (eds.), Information and Communication Overload in the Digital Age. Hershey, PA: IGI Global.

Gehrke, G. (eds) (2004) Digitale Teilung - digitale Integration. Perspektiven der Internetnutzung kompetenz (ECMC working paper, 5), Marl: Ecmc Europäisches Zentrum für Medien.

Geulen, D. (2005) 'Subjektorientierte Sozialisationstheorie. Sozialisation als Epigenese des Subjekts', in Interaktion mit der gesellschaftlichen Umwelt, Weinheim and München: Juventa-Verl.

Gigerenzer, G.; Gaissmaier, W. (2011) 'Heuristic decision making', in Annual review of psychology 62 (1), pp. 451-482. Doi: http://dx.doi.org/ 10.1146/annurev-psych-120709145346

Goldstein, D. G.; Gigerenzer, G. (1996) 'Satisficing inference and the perks of ignorance', in Proceedings of the 18th Annual Conference of the Cognitive Science Society.

Hartung, A. (2007) 'Das Fernsehen in der Lebenswelt älterer Menschen. Ergebnisse einer explorativen, qualitativen Befragung', in R. Rosenstock, C. Schubert and K. Beck (eds), Medien im Lebenslauf. Demographischer Wandel und Mediennutzung. München: kopaed, pp. 65-81.

Hartung, Anja (2009) 'Alter und Medienarbeit', in B. Schorb, G. Anfang and K. Demmler (eds), Grundbegriffe Medienpädagogik - Praxis, München: kopaed, pp. 1418.

Haubold, R. (2015) Silber ist das neue Bunt. Theoretische Exploration der Diversität der Medienaneignung älterer Menschen entlang ihrer Kontexte (unpublished Masterthesis), Universität Leipzig, Leipzig. Kommunikations- und Medienwissenschaft. 
Haubold, R. (2016) Löwen-Interviews. Motive der Smartphone- und Tabletnutzung (Manuscript), Leipzig.

Hepp, A. (2010) Cultural studies and Medienanalyse. Eine Einführung (Vol. 3), Wiesbaden: VS Verlag für Sozialwissenschaften.

Horn, J. L. (1979) 'Systematisierung von Daten zur Entwicklung menschlicher Fähigkeiten über die Lebensspanne hinweg', in P. B. Baltes and L. H. Eckensberger (eds), Entwicklungspsychologie der Lebensspanne (Klett-Cotta/Psychologie Forschung), Stuttgart: Klett-Cotta, pp. 263-307.

Hurrelmann, K. (1995) Einführung in die Sozialisationstheorie. Über den Zusammenhang von Sozialstruktur und Persönlichkeit (Vol. 5) (Beltz grüne Reihe), Weinheim: Beltz.

Hüther, J.; Podehl, B. (2010) 'Geschichte der Medienpädagogik', in J. Hüther and B. Schorb (eds), Grundbegriffe Medienpädagogik (Vol. 5), München: kopaed, pp. 116127.

Jäckel, M. (2010): 'Was unterscheidet Mediengenerationen? Theoretische und methodische Herausforderungen der Medienentwicklung'[online], in Media Perspektiven, 5, pp. 247-257. Available at http://www.mediaperspektiven.de/uploads/tx_mppublications/05-2010_Jaeckel.pdf. Accessed 28 April 2014.

Jahoda, M.; Lazarsfeld, P. F.; Zeisel, H. (1980) Die Arbeitslosen von Marienthal. Ein soziographischer Versuch über die Wirkungen langandauernder Arbeitslosigkeit; mit einem Anhang zur Geschichte der Soziographie (Vol. 3) (Edition Suhrkamp, 769), Frankfurt am Main: Suhrkamp.

Jenkins, H. (2008) Convergence Culture. Where Old and New Media Collide. New York, NY: New York University Press.

Jörissen, B.; Marotzki, W. (2009) Medienbildung - eine Einführung. Theorie - Methoden - Analysen (UTB, 3189), Bad Heilbrunn: Klinkhardt.

Katz, E.; Blumler, J. G.; Gurevitch, M. (1973) 'Uses and grafitications research', in The public opinion quarterly : journal of the American Association for Public Opinion Research, 37 (4), pp. 509-523.

Kogan, N. (1979) 'Kreativität und kognitiver Stil aus der Perspektive einer Entwicklungspsychologie der Lebensspanne', in P. B. Baltes and L. H. Eckensberger (eds), Entwicklungspsychologie der Lebensspanne (Klett-Cotta/Psychologie Forschung), Stuttgart: Klett-Cotta, pp. 229-262.

Krotz, F. (2008) Mediatisierung. Wiesbaden: Springer Fachmedien.

Kruse, A. (2002) 'Produktives Leben im Alter II: Der Umgang mit Verlusten und der Endlichkeit des Lebens', in R. Oerter and L. Montada (eds), Entwicklungspsychologie (Vol. 5), Weinheim: Beltz PVU, pp. 983-995.

Kruse, A. (2011) 'Offenheit, Generativität und Integrität als Entwicklungsaufgaben des hohen Alters', in C. Kollewe and E. Schenkel (eds) Alter: unbekannt. Über die Vielfalt des Älterwerdens. Internationale Perspektiven. Bielefeld: transcript (Sozialtheorie), pp. 243-260. 
Kubicek, H.; Welling, S. (2000) 'Vor einer digitalen Spaltung in Deutschland? Annäherung an ein verdecktes Problem von wirtschafts- und gesellschaftspolitischer Brisanz', $M \& K, 48$ (4), pp. 497-517.

Kübler, H.-D. (2012a) 'Digital Immigrants, silver surfer - oder digital prudents? Sekandäranalytische Sondierungen über defizitäre oder differenzierte Medienkompetenzen der älteren Generationen', in Medien \& Altern - Zeitschrift für Forschung und Praxis, 1, pp. 51-63.

Kübler, H.-D. (2012b) 'Mediengenerationen - gibt's die? Theoretische und analytische Sondierungen', in A. Hartung (eds), Generationen und Medienpädagogik. Annäherungen aus Theorie, Forschung und Praxis (Gesellschaft - Altern - Medien, 4), München: kopaed, pp. 41-64.

Künemund, H. (2001) Gesellschaftliche Partizipation und Engagement in der zweiten Lebenshälfte. Empirische Befunde zu Tätigkeitsformen im Alter und Prognosen ihrer zukünftigen Entwicklung (Beiträge zur Alterns- und Lebenslaufforschung, Bd. 3), Berlin: Weißensee Verlag.

Lauber, A.; Krapp, A. (2013) 'Interessengeleitete Medienaneignung. Ein Vorschlag zur Weiterentwicklung des Konzepts der Medienaneignung auf der Grundlage tätigkeitsund interessentheoretischer Überlegungen', in A. Hartung, A. Lauber and W. Reißmann (eds), Das handelnde Subjekt und die Medienpädagogik. Festschrift für Bernd Schorb. München: kopaed, pp. 89-106.

Leontjev, A. N. (1973) Probleme der Entwicklung des Psychischen (Vol. 4), Berlin: Volk und Wissen.

Livingstone, S. (2004) 'Media Literacy and the Challenge of new Information and Communication Technologies' [online], Available at http://eprints.Ise.ac.uk/1017/1/MEDIALITERACY.pdf. Accessed 12 May 2016.

Mahrt, M. (2014) 'Einstellung', in C. Wünsch, H. Schramm, V. Gehrau and H. Bilandzic (eds), Handbuch Medienrezeption, Baden-Baden: Nomos Verlagsgesellschaft, pp. 113-127.

Mannheim, K. (1970) 'Das Problem der Generationen', in K. Mannheim and K. H. Wolff (eds), Wissenssoziologie. Auswahl aus dem Werk. (Vol. 2), Neuwied: Luchterhand, pp. 509-565.

Marchart, Oliver (2011) 'Die politische Differenz. Zum Denken des Politischen bei Nancy, Lefort, Badiou, Laclau and Agamben' [online], Berlin: Suhrkamp (SuhrkampTaschenbuch Wissenschaft, 1956). Available at http://www.gbv.de/dms/fazrez/FD1201101032963834.pdf. Accessed 12 May 2016.

Matthes, Jörg (2014) 'Kognition', in C. Wünsch, Holger Schramm, V. Gehrau and H. Bilandzic (eds), Handbuch Medienrezeption, Baden-Baden: Nomos Verlagsgesellschaft, pp. 13-27.

Menning, S.; Hoffmann, E. (2009) 'Funktionale Gesundheit und Pflegebedürftigkeit', in Statistisches Bundesamt, Deutsches Zentrum für Altersfragen und Robert Koch-Institut (eds), Gesundheit und Krankheit im Alter. Beiträge zur Gesundheitsberichterstattung des Bandes, Berlin, pp. 62-78. 
Neugarten, B. L. (1979) 'Soziologische Betrachtung des Lebenslaufs', in P. B. Baltes and L. H. Eckensberger (eds), Entwicklungspsychologie der Lebensspanne (KlettCotta/Psychologie Forschung), Stuttgart: Klett-Cotta, pp. 361-378.

Patzwaldt, K.; Staudinger, U. M. (2012) 'Medien und Altern: Forschungsperspektiven zur produktiven Entwicklung Erwachsener', in Medien \& Altern - Zeitschrift für Forschung und Praxis (1), pp. 64-75.

Paus-Hasebrink, I. P. (2013) 'Medienwelten, Medienhandeln, Medienaneignung, Medienkompetenz. Medienpädagogische Theoriebausteine überdacht', in A. Hartung, A. Lauber and W. Reißmann (eds), Das handelnde Subjekt und die Medienpädagogik. Festschrift für Bernd Schorb, München: kopaed, pp. 25-40.

Pietraß, M.; Grengs, A.-K. (2012) 'Mediengenerationen. Gibt es Unterschiede zwischen jüngeren and älteren Nutzern?', in A. Hartung (eds), Generationen und Medienpädagogik. Annäherungen aus Theorie, Forschung und Praxis (Gesellschaft - Altern - Medien, 4), München: kopaed, pp. 25-40.

Prensky, M. (2001) 'Digital natives, digital immigrants', in On the Horizon 9 (5).

Renckstorf, K. (1977) Neue Perspektiven in der Massenkommunikationsforschung. Beiträge zur Begründung eines alternativen Forschungsansatzes (Beiträge zur Medientheorie and Kommunikationsforschung, 16) [online], Berlin: Spiess. Available at http://www.gbv.de/dms/faz-rez/780119_FAZ_0021_21_0007.pdf. Accessed 12 May 2016.

Saß, A.-C.; Wurm, S.; Ziese, T. (2009) 'Alter = Krankheit? Gesundheitszustand und Gesundheitsentwicklung', in Statistisches Bundesamt, Deutsches Zentrum für Altersfragen und Robert Koch-Institut (eds), Gesundheit und Krankheit im Alter. Beiträge zur Gesundheitsberichterstattung des Bundes, Berlin, pp. 31-61.

Schenk, H. (2011) 'Vorhang auf für die neuen Alten! Vom allmählichen Wandel unseres kulturellen Altersbildes', in C. Kollewe and E. Schenkel (eds), Alter: unbekannt. Über die Vielfalt des Älterwerdens. Internationale Perspektiven (Sozialtheorie), Bielefeld: transcript, pp. 27-39.

Schenk, M. (2007) Medienwirkungsforschung (Vol. 3), Tübingen: Mohr Siebeck.

Schirrmacher, F. (2004) Das Methusalem-Komplott, München: Blessing.

Schneider-Flume, G. (2008) Alter - Schicksal oder Gnade? Theologische Überlegungen zum demographischen Wandel und zum Alter(n), Göttingen: Vandenhoeck \& Ruprecht.

Schorb, B. (1995) Medienalltag und Handeln. Medienpädagogik im Spiegel von Geschichte, Forschung und Praxis, Opladen: Leske + Budrich.

Schorb, B. (2009) 'Medienaneignung', in B. Schorb, G. Anfang and K. Demmler (eds): Grundbegriffe Medienpädagogik - Praxis, München: kopaed, pp. 182-186.

Schorb, B.; Theunert, H. (2000) 'Kontextuelles Verstehen der Medienaneignung', in I. Paus-Haase and B. Schorb (eds), Qualitative Kinder- und Jugendmedienforschung. Theorie und Methoden: ein Arbeitsbuch, München: kopaed, pp. 33-57.

Schulze, G. (1997) Die Erlebnis-Gesellschaft. Kultursoziologie der Gegenwart (Vol. 7), Frankfurt/Main, New York: Campus-Verl. 
Simon, G.; Haring, S.; Noack, H.; Reis-Klingspiegl, K. (1999) Altern als Herausforderung (Schriftenreihe / Arbeitsgemeinschaft für Sozialforschung und Sozialplanung Steiermark, 7), Graz: Leykam.

Stadelhofer, C.; Marquard, M. (2012) 'Internetnutzung älterer Erwachsener in der allgemeinen wissenschaftsfundierten Weiterbildung', in B. Kampmann, B. Keller, M. Knippelmeyer and F. Wagner (eds), Die Alten und das Netz : Angebote und Nutzung jenseits des Jugendkults, Wiesbaden: Gabler, pp. 124-142.

Wegener, C. (2008) Medien, Aneignung und Identität. 'Stars' im Alltag jugendlicher Fans, Wiesbaden: VS Verlag für Sozialwissenschaften. Available at http://dx.doi.org/10.1007/978-3-531-90833-5. Accessed 12 May 2016.

Weise, K. (2007) 'Osteoporoseassoziierte Frakturen: Alterstraumatologie eröffnet heute große Chancen' (02.02.2007), in Deutsches Ärzteblatt 104 (5), pp. 238-242. Available at http://www.aerzteblatt.de/archiv/54291/Osteoporoseassoziierte-FrakturenAlterstraumatologie-eroeffnet-heute-grosse-Chancen. Accessed 18. December 2014.

Zelić, T. (2008) On the Phenomenology of the Life-World. in Synthesis philosophica 46 (2), pp. 413-426. Retrieved Nov. 16, 2016, Available at: http://hrcak.srce.hr/file/58496. Accessed 18. December 2014.

Ziegler, A. (2008) 'Osteoporose: Vermehrte Knochenfrakturen genetisch bedingt', Deutscher Apotheker Verlag, K. G. Brauer and P. Ditzel, (eds), Deutsche Apotheker Zeitung (36). Available at http://www.deutsche-apotheker-zeitung.de/dazausgabe/artikel/articlesingle/2008/36/27027.html. Accessed 18. December 2014.

Zinnecker, Jürgen (2003) '"Das Problem der Generationen". Überlegungen zu Karl Mannheims kanonischem Text', in J. Reulecke (eds), Generationalität und Lebensgeschichte Im 20. Jahrhundert. München: Oldenbourg, pp. 33-58.

Rebekka Haubold, M.A. is a graduate assistant under Prof. Sonja Ganguin at the Institute of Communication and Media Research, University of Leipzig, Germany. She is a member of the cross-generational media-project "Medienclub Leipziger Löwen"

Email: rebekka.haubold@uni-leipzig.de

Sonja Ganguin, Prof. Dr. phil. is a professor of Media Education and her research focuses on exploring the processes of media appropriation and the educational application of the media at the Institute of Communication and Media Research, University of Leipzig, Germany.

Email: sonja.ganguin@uni-leipzig.de 